\title{
HERITAGE EDUCATION AND STUDENTS' TRAINING - CASE STUDY FACULTY OF HUMANITIES UNIVERSITY OF PRIMORSKA

\section{IRENA LAZAR - ZRINKA MILEUSNIĆ}

\section{ABSTRACT/ABSTRAKT:}

The University of Primorska Faculty of Humanities (Slovenia) offers Bologna programmes covering the topics of heritage and heritage studies on undergraduate and postgraduate levels. An important part of the study and students' training is practical work on sites and monuments and collaboration with local community. Insights and skills acquired during the course of study introduce students to the specifics of Istria, Slovenia and the Mediterranean, guiding them to understand various heritage fields and cultural assets within a wider European and international setting. One of the courses (Heritage Tourism study course) was designed as cooperation between the Faculty of Humanities, Faculty of Tourism Studies Portorož - Turistica. It is based on estimates about the need for a broader and more quality inclusion of cultural heritage in the current tourist offer in Slovenia and abroad, in part due to a lack of suitably educated professionals. Study course is the first of its kind in Slovenia to fill in the void in higher education in the field of heritage, heritage management and cultural tourism.

Vzdělávání v oblasti kulturního dědictví a praktická průprava studentů - případová studie Fakulty humanitních věd Univerzity v slovinském Přímoří

Fakulta humanitních věd Univerzity v slovinském Přímoří nabízí $\mathrm{v}$ rámci Boloňského procesu studijní programy zaměřené na problematiku kulturního dědictví a památkové péče na bakalářském, magisterském i doktorském stupni. Důležitou součástí studia a průpravy studentů je jejich zapojení do praktických činností prúmo na lokalitách a památkách, kde spolupracují s místní komunitou. Díky vědomostem a dovednostem získaným během studia se studenti obeznámí se specifickými problémy týkajícími se regionů Istrie, Slovinska a Středomoří a získají přehled o různých oblastech $\mathrm{v}$ rámci kulturního dědictví a památek v evropském i mezinárodním kontextu. Jeden ze studijních kurzů (Kulturní turizmus) byl vytvořen $\mathrm{v}$ rámci spolupráce Fakulty humanitních věd s Fakultou cestovního ruchu Turistica v Portoroži. Kurz vychází z potřeby širšího a kvalitnějšího zapojení kulturních památek do existující nabídky turistických míst v Slovinsku i v zahraničí a částečně je také reakcí na nedostatek adekvátně vyškolených odborníků. Tento studijní kurz je prvním svého druhu v rámci Slovinska a jeho cílem je zaplnit mezeru ve vyšším vzdělávání v oblasti kulturního dědictví, managementu památkové péče a kulturního turizmu.

\section{KEYWORDS/KLÍČOVÁ SLOVA:}

heritage education - students' training - heritage management heritage tourism - dissemination Slovenia vzdělávání v oblasti kulturního dèdictví - praktická průprava studentů - management památkové péče - kulturní turizmus - šírení informací - Slovinsko

The University of Primorska Faculty of Humanities (Slovenia) offers several Bologna programmes covering the topics of heritage studies (museology) and heritage management. An important part of the study and students' training is also practical work on sites and monuments.

The Faculty of Humanities was established in 2000 as an independent institution of higher education in Koper, becoming an affiliate of the University of Primorska in 2003. ${ }^{1}$ The Faculty of Humanities offers both undergraduate and postgraduate degree courses as well as engaging in scientific and specialist activities in the field of humanities, arts and social studies. ${ }^{2}$ To insure the highest quality in its activities on all these fields the Faculty promotes the following core values: excellence of study courses; continuous development of infrastructure and equipment; highly qualified and experienced staff; working in a harmonious professional environment; enhanced attention to the well-being of students; creating better

1 ČOK, Lucija. Hic et nunc aude. Ustanovitev Univerze na Primorskem $v$ času in prostoru. Koper: Založba ZRS UP, 2013, p. 62 sq.

2 University of Primorska, Faculty of Humanities [online]. [accessed 2018-02-12]. Available from www: <http://www.fhs.upr.si/en>. 
employment opportunities in a highly efficient support network both within the University of Primorska, the wider academic field in Slovenia, as well as internationally.

The Faculty of Humanities has gained recognition for its dynamic outlook due to its progressive orientation, its creativity and capacity for critical thinking, as well as the collaboration of its dedicated teaching staff together with students in an atmosphere of mutual support. The Faculty enjoys the advantage of being situated in the multicultural and bilingual area bordering on Italy and Croatia, providing the potential for drawing on positive cultural and economic influences. Insights and skills acquired during the course of study introduce students to the specifics of Istria, Slovenia and the Mediterranean, guiding them to understand diversity, multiculturalism and the variety of heritage and its influences within a wider European and international setting.

The Department for Archaeology and Heritage was established with an objective of offering complex education in the field of archaeology and cultural heritage. This included general overviews of all relevant fields dealing with cultural heritage, such as archaeology, art history, architecture, ethnology, but also covering the topics of legal protection, conservation, preservation, promotion, interpretation and museology. With this kind of study programme quality education in the field of cultural heritage was ensured and as such it was the first its kind in Slovenia.

Parts of our heritage education programmes are explained in the following chapters with the goal to point out the specifics of the knowledge they are offering.

\section{Undergraduate Bologna courses Cultural Heritage (BA)}

This study course provides knowledge of heritage in the broad sense of the term and basic rules governing heritage protection, as well as its importance in modern life. The knowledge of heritage will bridge a professional gap in the fields of natural and cultural heritage preservation, protection, development, and marketing, which bears vital importance for Slovenia in further European integration processes and is applicable in particular to the Slovene coastal area and hinterland, situated at the sensitive intersection among three states and cultural systems. In addition to basic subjects, the European and Mediterranean Heritage course offers numerous elective subjects within this field of study, as well as other fields and scientific disciplines.

\section{Graduates of the Heritage} course have opportunities for professional employment within the framework of public institutions for the protection and promotion of cultural heritage. Employment potential could be found within the framework of national, regional and thematic museums, regional units of the Institute for the Protection of Cultural Heritage of Slovenia or the Institute for the Protection of Natural Heritage of Slovenia. The broad general knowledge and knowledge of cultural heritage enable graduates to seek employment opportunities within cultural editorial boards of different media (cultural editorial boards of TV channels, radio stations, newspapers, and magazines), while their knowledge of legal procedures enables them to work in public administration in the field of heritage documentation and cultural and tourism activities coordination, in tourism in relation to the incorporation of heritage into tourism supply, in non-governmental organisations for heritage protection and preservation; in addition, the possibility of self-employment in culture- in heritage-related activities and promotion should be emphasized. Unfortunately, the general interest for this kind of study has lessened in the last decade. That is why the study course is in the process of renovation and will be combined with the study programme Cultural Tourism with the Faculty of Tourism Studies. It is planned to offer new joint study programme Cultural Tourism and Cultural Heritage as an interdisciplinary programme on undergraduate level in 2020 that will be conducted jointly by both faculties. With these changes we aim to educate students on the interdisciplinary level of both cultural heritage and tourism at the beginning of their studies or at the undergraduate level.

\section{Postgraduate courses Archaeological Heritage of the Mediterranean (MA)}

The course Archaeological Heritage of the Mediterranean is designed to deepen and widen the professional training of a student in the field of archaeology and archaeological heritage, whereby the educational process includes theoretic aspects, as well as the transfer of knowledge for applicative use in institutions dealing in research, protection, promotion and marketing of archaeological heritage. During their studies students develop an in-depth insight into the state and development of concepts in archaeology and archaeological heritage protection, get to know the fundamental practical scientific methods of archaeological, conservation and museum work, understand the conceptual affiliation of knowledge into 
a wider context of disciplines concerned with the research, protection and promotion of archaeology and cultural heritage, develop the ability of solving concrete problems in the field, and an ability to use the results for theoretical scientific work, as well as acquaint themselves with the work process from fundamental research to the preparation of scientific publications.

In the framework of their studies, students have an opportunity to be involved in the research work early on through the Institute for Archaeology and Heritage at the Faculty of Humanities. Additionally, they have access to a well-stocked scientific library, can take part in national and international scientific and professional meetings, in field research, as also in the summer school of museology organised every year since 2007. An important part of the study and education about archaeological heritage in practice are excursions, visits and interviews. Organised tours of archaeological collections, sites, monuments, parks, museums, etc. give students an opportunity to face the problems, projects, and state in the field of archaeological heritage, while at the same time enabling an authentic and informal contact to the field, professors, and a mutual exchange of opinions and views about questions linked to their studies. The course combines various elements of practical training and research work and provides a varied employment range for the graduates. Very important are also the possibilities of student exchange and their participation in programmes like, e. g. Leonardo da Vinci, Jean Monet, Erasmus+, Ceepus, Archeoped, and in the frame of the UNESCO Unitwin Network for Underwater Archaeology ${ }^{3}$ or UNESCO Chair of Museology and World Heritage. ${ }^{4}$

\section{Heritage \& Tourism $(M A)^{5}$}

The new Heritage Tourism study course was designed from cooperation between the Faculty of Humanities, Faculty of Tourism Studies Portorož - Turistica, and Science and Research Centre of the University of Primorska based on estimates about the need for a broader and more quality inclusion of cultural heritage in the current tourist offer in Slovenia and abroad, due in part to a lack of suitably educated professionals. ${ }^{6}$ The study course is the first of its kind in Slovenia to fill in the void in higher education in the field of tourism and heritage, where these two independent disciplines overlap, but not integrate in a combination of topics, as the University of Primorska has the appropriate professional and research potential available. The Heritage Tourism study course offers skills and competences in the field of cultural heritage and tourist management with emphasis on the implementation of heritage contents into the tourist offer. In this way students receive an education enabling creative work in a promising economic discipline. The aim of the study course is to develop an MA student profile to engage the work needs in tourism, as well as independent entrepreneurial activities in tourism. The course is

\footnotetext{
3 UNESCO UNITWIN Underwater Archaeology Network [online]. [accessed 2018-02-12]. Available from www: <http://www.fhs.upr.si/en>.

4 UNESCO Chair of Museology and World Heritage [online]. [accessed 2018-02-12]. Available from www: <https://archeo-muzeo.phil.muni.cz/en/ about/katedra-unesco $>$.

5 joint programme with the Faculty of Tourism Studies Portorož - Turistica

6 University of Primorska, Faculty of Humanities [online]. [accessed 2018-02-12]. Available from www: <http://www.fhs.upr.si/en>.
}

interdisciplinary and is conducted jointly by Turistica and Faculty of Humanities; the enrolment is open to all students with a BA in humanities, tourism and other fields.

The Faculty of Humanities is inviting applications for enrolment in several postgraduate courses, we could single out History of Europe and the Mediterranean, Geography, Management of Cultural Assets and Archives, and Archaeology. The courses provide a variegated selection of contents and hence allow postgraduate students to create individualised study courses tailored to their interests. The lecture cycles enable group work and socialising among students who can exchange experience in and knowledge of specific topics inherent to their study discipline. The existing postgraduate courses are currently being renovated, while new postgraduate MA and $\mathrm{PhD}$ courses in fields that have so far only been available at the undergraduate level or entirely new are being prepared. With these courses we aim to train qualified, open, and learned graduates who will confidently and critically enter the job market and will be capable of efficient operation during these times of incessant cultural, social, political and economic changes permeating Slovenia, Europe, and the entire global community.

\section{Students and practical experience / training}

An important part of the study and students' training is also the research and practical work on sites and monuments. This includes excavations, field surveys, use of non-destructive methods on sites, processing of the archaeological material, as well as didactical work, and dissemination. One of the sites where students train and develop their understanding of heritage 
protection and management is the villa maritima Archaeological park Simonov zaliv in Izola. ${ }^{7}$

The site of villa maritima - The Roman villa and the port of Simonov zaliv (St. Simon's Bay) were first mentioned as an archaeological site in the 16th century. ${ }^{8}$ The first archaeological excavation took place in 1922 , when the remains of the harbour were measured for the first time. The residential part of the villa stretches across a surface of $3,000 \mathrm{~m}^{2}$; the living quarters are arranged around an inner courtyard, while the whole complex is connected by a portico to the port. Recent excavations have brought to light new information about the villa's history, the villa was built between 25 and 10 BC. Parts of the residential area were already abandoned between 50 and $70 \mathrm{AD} .{ }^{9}$ The portico and the port were in use through a longer time period. In the early medieval period, the church of St. Simon was built on the property, giving the bay its name. Various finds were discovered during the excavations in the villa of Simonov zaliv, from which the life of the villa's inhabitants and the economic

7 ZANIER, Katharina. La villa maritima d S. Simone a Izola/Isola (Slovenia). Progetti e interventi per la valorizzazione scientifica e turistica. In CORALINI, Antonella (ed.) Vesuviana. Archeologie a confronto. Atti del convegno internazionale (Bologna, 14-16 Gennaio 2008). Bologna: Ante Quem, 2009, p. 321 sq.; LAZAR, Irena and Zrinka MILEUSNIĆ. Heritage interpretation as part of the heritage study programmes in Koper. In Spring Event 2017: Proceedings: 19-21 May 2017 in Prague [online]. Witzenhausen: Interpret Europe, 2017, pp. 59-67 [accessed 2018-02-12]. Available from www: $<$ http://www.interpret-europe.net/fileadmin/ news-tmp/ie-events/2017/Prague/ieprague17_ proceedings.pdf $>$

8 STOKIN, Marko and Katharina ZANIER. Simonov zaliv / San Simone, Ljubljana: ZVKDS, 2011, p. 48 sq. Vestnik, vol. 23.

9 GROH, Stefan and Helga SEDLMAYER. Die Grabungen in der römischen Villa Maritima von San Simon bei Isola, Slowenien. Annales, Series Historia et Sociologia, 2008, vol. 18, no. 2, pp. 385-396; GROH, Stefan and Helga SEDLMAYER. Otium cum dignitate et negotium trans mare. La villa marittima di San Simone (Simone zaliv) in Istria (Slovenia). Bologna: Ante Quem, 2016. branches in which they were employed can be reconstructed. Some of the discovered objects can be seen in the Maritime Museum Sergej Mašera in Piran and in the Regional Museum of Koper.

Around the beginning of the Common Era Seaside villas were built since the 1st century BC and on along the whole Istrian coast in the distance every few kilometres. Such villa complexes were usually made up of a representative residential part, outbuildings, and a harbour with storage facilities. These residences were important economic focus-points, where fish and shells were bred, wine and olives cultivated and produced, brick and amphorae manufactured, sheep bred and wool processed, while the warehouses were used to store and reload the goods imported through the sea.

The Roman harbour of the villa in Simonov zaliv was one of the largest on the western coast of Istria, covering a surface of over $7,000 \mathrm{~m}^{2}$. It was well protected from the wind and could receive ships of more than 25 metres in length. The embankment and the pier, which still had bronze mooring rings in the 19th century, are now covered by the public baths complex. The remains of the breakwater are still visible in the sea under sea level, as the sea level today is 1.6 metres higher than it was in the Roman period. The harbour remained in use until the Early Middle Ages.

\section{Site as a cultural monument of national importance}

The Simonov zaliv archaeological site, managed by the Institute for Archaeology and Heritage FHŠ $\mathrm{UP}$, is a nationally important cultural monument; ${ }^{10}$ these most thoroughly researched remains of

10 ID number of the monument in the national immovable heritage database - EŠD 195. a Roman villa with a port were not suitable presented or accessible. The remains of the villa were also endangered by the underground water and the sea tides. The decree on the archaeological site of Simonov as a nationally important cultural monument ${ }^{11}$ stipulates as follows:

- to keep the monument as a whole, as is, and intact;

- that all alterations, made to the monument as a whole or to its parts, are forbidden;

- that any use of the monument, its parts or its surrounding area, should be beneficial to keeping and preserving its value as a whole;

- that any change, made to the archaeological layers of the monument, are forbidden to unauthorized personnel; interventions are only possible with the prior consent of the responsible institution;

- and that the monument should be presented as a whole or in parts in a manner and to the extent that does not damage it.

The decree also stipulates that the protected area serve:

- the perpetual keeping of the monument and its values,

- augmenting the testimonial value of the monument,

- the presentation of the monumental cultural values in situ, in printed media and elsewhere, in teaching and research.

Still, it took as long as until 2004 for another initiative for the monument's promotion and presentation to take shape; the institute reached an agreement with the Municipality of Izola and the Institute for the Protection of Cultural Heritage in 2010,

11 Publication of the document in the Official Journal of the Republic of Slovenia: Ur. 1. RS, št. 81/99-3854, str. 12618-12619. 
according to which it assumed the unofficial role of the manager of the site.

In the past years several activities were conducted for the valorization and promotion of the site; since 2010 the University of Primorska, specifically the Institute for Archaeology and Heritage of the Faculty of Humanities is responsible for the management of this monument (owned by the Municipality of Izola). The mosaics are an essential architectural segment of the archaeological remains and were in particular need of protection. ${ }^{12}$ It was important to ensure protective constructions, i.e. coverings over the mosaics that will ensure their long-term preservation.

\section{The Project AS - Archaeology for all}

University of Primorska secured a grant as a leading partner from the EAA 2009-2014 tender, section B - Cultural Heritage. The project AS - Archaeology for all: revival of the Archaeological park Simonov zaliv (slov. AS - Arheologija za vse: oživljanje arheološkega parka Simonov zaliv) started in February 2015 and was concluded in January 2017. Project leader was the author of this article.

Among the objectives in the segment of cultural heritage was "to preserve and restore cultural monuments, accessible to the general public and contributing to the local and regional development, augmenting tourist offer and boosting the recognisability of the local or regional environment". Another objective was to contribute

12 BOGOVČIČ, Ivan. Ostanki antičnih mozaikov in fresk v Simonovem zalivu. Varstvo spomenikov, 1994, 35, pp. 7-17; LAZAR, Irena. La villa romana nella baia di San Simone - possibilità do presentazione dei mosaici. In STOKIN, Marko and Sabina KRAMAR (eds.). Mozaiki severnega Jadrana / I mosaici dell'alto Adriatico. Koper: ZVKDS, 2011, pp. 161-174. Vestnik, vol. 24. to the knowledge about the meaning of preserving cultural heritage, about its development potential and the particularities of its preservation and restoration. The leading partner should also allocate at least $5 \%$ of funds for the "soft" activities, i.e. better accessibility of cultural heritage (e. g. attractive programmes for vulnerable groups and the young population). The latter objective required the cooperation of the didactics-oriented members of the university as well as including students into the project activities. ${ }^{13}$

\section{Granted proper financial} stimulation of the financial mechanism EAA, the applicant and its partners made all necessary steps within the proposed project, for the establishing of a modern archaeological park (including the underwater section of the site). Increasing the long-term accessibility of the site will be ensured primarily by the presentation of the archaeological site of Simonov zaliv, the established first underwater archaeological trail in Slovenia, a modern interpretation centre in the archaeological park, increased tourist offer with the aid of itineraries with cultural contents and increased accessibility for visitors with disabilities, ensuring properly customized contents and activities. ${ }^{14}$

\section{Student collaboration}

The varied activities connected to the work on the archaeological site of the Roman maritime

\footnotetext{
13 LAZAR, Irena. Izobraževanje na področju kulturne dediščine: Fakulteta za humanistične študije Univerze na Primorskem. Studia Universitatis Hereditati, 2013, vol. 1, no. 1/2, pp. 123-139; LAZAR, Irena. Arheološki parki in poti $v$ Sloveniji / Parchi e itinerari archeologici in Slovenia. Ljubljana: ZVKDS, 2014

14 LAZAR, Irena. AS - Arheologija za vse: oživljanje arheološkega parka Simonov zaliv: priročnik projekta / AS - Archaeology for all: revival of the archaeological park Simonov zaliv: project manual. Koper: Založba Univerze na Primorskem, 2016.
}

villa and the formation of an archaeological park offer an excellent opportunity to combine scientific research and university education..$^{15}$ Archaeology, heritage, history, museology, restoration, conservation and tourism are only some of the contents where students have contributed, deepening and expanding their knowledge in the framework of the official study process or workshops and summer schools.

In the framework of undergraduate and graduate study programmes students participating the heritage courses at the University of Primorska prepare seminars and final papers on themes of Greek and Roman history, Roman villas, Roman religion, life in Roman period, archaeological sites in the Slovenian coast, analyses of archaeological material, and conducted numerous surveys about the visibility of the site, its tourist opportunities, etc. Under the mentorship of professors from the Department of Archaeology and Heritage and researchers and collaborators of the Institute for Archaeology and Heritage of our Faculty students also participate the annual field research, conservation and management of the site throughout the year, practical work in the park also included preparation, participation and implementation of public events. In this way they expanded the course topics in various subjects and gained practical experience for work and public programmes on the site.

The villa was also included as an archaeological site into the programme of conservation and archaeological workshops organized in collaboration with

15 LAZAR, Irena. Villa maritima in San Simon Heritage Studies and archaeological Park. In Cultural Heritage and sustainable Development of Local Communities. Prague: Charles University, 2013, pp. 94-107. 
the Institute for the Protection of Cultural Heritage of Slovenia. In the framework of the conservation workshop students collaborated with foreign and national experts ${ }^{16}$ and the cleaning of the black-andwhite mosaic and its consolidation was undertaken. During the course of the work the necessary tests were made to determine the most suitable methodology for cleaning and strengthening the mosaics on site. ${ }^{17}$ The International Archaeological Workshop 2011 Magdalensberg, organised by the Austrian Archaeological Institute (ÖAI) from Vienna, the Landesmuseum Kärnten from Klagenfurt, and the Institute for Mediterranean Heritage, SRC Koper, UP, offered students from universities in Vienna, Graz, Ljubljana and Koper an opportunity to visit and work at the main archaeological sites in the northern Adriatic in the framework of a practical study of Roman material culture (ceramics, glass, mosaics).

The students who express their interest for an even closer and longer cooperation in the work and activities linked to the villa in Simonov zaliv, have the opportunity to continue their work also in the summer months and outside their study time as volunteers. During 2015 and 2016 they had an opportunity to participate free educational courses with additional topics on cultural and natural heritage within the

\footnotetext{
16 The workshop took place between July 13 and 182011 and was organised by Triptih d.o.o. and the Restoration Centre of the Institute for the Protection of Cultural Heritage of Slovenia, Department of wall painting, in collaboration with Michele Macchiarola of the CNR - Institute of Science and Technology for Ceramics from Faenza (Italy) and Nikola Upevče from Macedonia.

17 LAZAR, Irena. La villa romana nella baia di San Simone - possibilità do presentazione dei mosaici. In STOKIN, Marko and Sabina KRAMAR (eds.). Mozaiki severnega Jadrana / I mosaici dell'alto Adriatico. Koper: ZVKDS, 2011, pp. 161174. Vestnik, vol. 24.
}

project AS. Archaeology for all, ${ }^{18}$ during the summer they could work in the park as guides (conditioned by their knowledge of English and Italian, and suitable archaeological contents), and contribute to the implementation of pedagogic and long life learning workshops and other activities in the park, as well as public events (international museum day, summer museum night). The themes of the pedagogic workshops include making a mosaic, making jewellery, what is an amphora, living like the Romans, experimental archaeology, etc., and were prepared with the help of students. Some of the graduates already lead the workshops independently.

The International Summer School of Museology, ${ }^{19}$ taking place in Piran and Koper since 2007, organised by the Faculty of Humanities and later also in cooperation with the Forum of Slavic Cultures and European Museum Academy, links its annual topics to ICOM's annual themes at the international day of museums on May 18. The chosen themes of museums and heritage management, cultural tourism and museum presentations could thus be connected with the activities at the villa in Simonov zaliv. Students could acquire 3 ECTS by participating in the summer school, which provides five days of lectures, seminars and workshops, excursions and practical work; the official language of the school is English.

Since 2016 the Ministry of Education RS and ESS publish a call entitled PKP - Creative paths to knowledge. It supports and

18 AS. Project Archaeology for all / Projekt Arheologija za vse [online]. [accessed 2018-02-12]. Available from www: <https://www.project-as. eu/en/>

19 Oddelek za arheologijo in dediščino. In Univerza na Primorskem, Fakulteta za humanistične študije [online]. [accessed 2018-02-12]. Available from www: <http://www.fhs.upr.si/sl/oddelki/ oddelek-za-arheologijo-in-dediscino $>$. fosters the collaboration between universities and the corporative sector, including working mentors in the process of practical work of students. Project teams include 6 to 8 students, 1-2 pedagogical and 1-2 working mentors. Main focus of these projects is to offer the possibility for students to find creative and innovative solutions to practical challenges. The important part of the project is also a small financial award for the collaborating students, thus giving them practical experience and financial support. Faculty of Humanities has so far directed ten PKP projects, mainly oriented on cultural heritage. Our collaboration included UNESCO sites, museums, private companies, etc. Working and collaborating this way students can also establish direct links with the potential future employers. ${ }^{20}$

Graduates of the study courses in heritage studies have opportunities for professional employment within the framework of public institutions for the protection and promotion of cultural heritage. Therefore, it is extremely important for the students to gain as much practical experience as possible during their studies in the fields of heritage research, protection, and promotion. In this way, they can become directly acquainted with different fields of work, but also the positive and negative aspects of heritage protection. Moreover, they thus have an opportunity to get to know various institutions and organisations, which have the potential to become their future employers.

\section{Local society}

With the organization of didactic workshops for children since 2008

20 Creative path of knowledge. In Public Scholarship, Development, Disability, Maintenance Fund of the Republic of Slovenia [online]. [accessed 2018-02-12]. Available from www: <http://www. sklad-kadri.si/en/human-resources-development/ creative-path-to-knowledge $>$. 
and on, the work in Archaeological park Simonov zaliv in Izola became well-known and gained interest of several public institutions who expressed interest for collaboration. Since 2010 we developed the long life learning programme of workshops in collaboration with City Library Izola. We invited experts for mosaics, stone-cutting, ancient jewellery, costumes, etc. These workshops were organized as basic and advanced courses and took place at the site or in the library premises during the winter period. Additional programme included public lectures with the topics on archaeology, heritage, heritage management, local history, etc. and were open to the public.

This collaboration led further to the local schools and from the year 2011 our programme out of the summer season is oriented to workshops, lectures and other activities that we implement in the frame of the school programmes. This collaboration developed mutually and as an example can be mentioned the Secondary School for Tourism in Izola. During their practical work they have prepare food from the Roman recipes we selected for them and their meals were offered to the visitors. Students informed visitors about the ancient diet, how to prepare the specific food, about ancient spices and their use in modern nutrition.

\section{Conclusion}

Heritage programmes aim to transfer the basic knowledge required for the understanding and research of heritage and at the same time the basis for the development of students' own interests and further development in the field of heritage in general as well in specific areas such as legislation, conservation, restoration, museology and tourism.
Students that have finished heritage courses stay involved in the activities in the archaeological park by working as guides, preparing and implementing workshops and collaborating in other ways. In one of our ongoing projects they had the opportunity to prepare a set of workshops for children. They have shown a great level of indipendency by preparing workshops, programme for teaching a foreign language through the heritage workshops, connecting sport activities with heritage and promoting their own activities.

The most important outcome that we can trace is that they work in the field of heritage on different levels and work as indipendent professionals in collaboration with other institutions such as libraries, museums, heritage sites. They design their own heritage products or offer and perform it in the above mentioned institutions. Topics that they cover are mostly connected or derive from the roman heritage from the site of Simonov zaliv and they include it in the forms of storytelling, historical reenactment and other means of interpretation.

In conclusion, we can emphasise that including the Archaeological park Simonov zaliv in Izola into the study process of the Department of Archaeology and Heritage at the Faculty of Humanities University of Primorska is a good example of integrating studies and practical and research work, while at the same time also opening new paths of cooperation with the local community and in finding employment opportunities for the students.

The Department is already working on the further collaboration and networking with international institutions such as ICOM, ICOMOS and UNESCO, and with several national institutions in the field of cultural heritage, for example it is including students experience on the projects in the programme of the International Summer School of Museology.

\section{BIBLIOGRAPHY:}

AS. Project Archaeology for all / Projekt Arheologija za vse [online]. [accessed 2018-02-12]. Available from www: <https://www.project-as.eu/en/>. BOGOVČIČ, Ivan. Ostanki antičnih mozaikov in fresk v Simonovem zalivu. Varstvo spomenikov, 1994, vol. 35, pp. 7-17. ISSN 0350-9494.

Creative path of knowledge. In Public Scholarship, Development, Disability, Maintenance Fund of the Republic of Slovenia [online]. [accessed 2018-02-12]. Available from www: <http:// www.sklad-kadri.si/en/humanresources-development/creative-path-to-knowledge $>$.

ČOK, Lucija. Hic et nunc aude. Ustanovitev Univerze na Primorskem $v$ času in prostoru. Koper: Založba ZRS UP, 2013. ISBN 978-961-6732-33-8.

GROH, Stefan and Helga SEDLMAYER. Die Grabungen in der römischen Villa Maritima von San Simon bei Isola, Slowenien. Annales, Series Historia et Sociologia, 2008, vol. 18, no. 2, pp. 385396. ISSN 1408-5348.

GROH, Stefan and Helga SEDLMAYER. Otium cum dignitate et negotium trans mare. La villa marittima di San Simone (Simone zaliv) in Istria (Slovenia). Bologna: Ante Quem, 2016. ISBN 88-7849-116-0.

LAZAR, Irena. La villa romana nella baia di San Simone - possibilità di presentazione dei mosaici. In STOKIN Marko and Sabina KRAMAR (eds.). Mozaiki severnega Jadrana / I mosaici dell'alto Adriatico. Ljubljana: ZVKDS, 2011, pp. 161-174. Vestnik, vol. 24.

LAZAR, Irena. Villa maritima in San Simon - Heritage Studies and archaeological Park. In Cultural Heritage and sustainable Development of Local Communities. Prague: Charles University, 2013, pp. 94-107. 
LAZAR, Irena. Izobraževanje na področju kulturne dediščine: Fakulteta za humanistične študije Univerze na Primorskem. Studia Universitatis Hereditati, 2013, vol. 1, no. 1/2, pp. 123-139. E-ISSN 2350-5443.

LAZAR, Irena. Arheološki parki in poti v Sloveniji / Parchi e itinerari archeologici in Slovenia. Ljubljana: ZVKDS, 2014. ISBN 978-961-6902-64-9.

LAZAR, Irena. AS - Arheologija za vse: oživljanje arheološkega parka Simonov zaliv: priročnik projekta / AS - Archaeology for all: revival of the archaeological park Simonov zaliv: project manual. Koper: Založba Univerze na Primorskem, 2016. ISBN 978-961-6984-56-0. ISBN 978-961-6984-68-3.

LAZAR, Irena and Zrinka MILEUSNIĆ. Heritage interpretation as part of the heritage study programmes in Koper. In Spring Event 2017: Proceedings: 19-21 May 2017 in Prague [online]. Witzenhausen: Interpret Europe, 2017, pp. 59-67 [accessed 2018-02-12]. Available from www: <http://www. interpret-europe.net/fileadmin/newstmp/ie-events/2017/Prague/ieprague17. proceedings.pdf $>$.

Oddelek za arheologijo in dediščino. In Univerza na Primorskem, Fakulteta za humanistične študije [online]. [accessed 2018-02-12]. Available from www:

$<$ http://www.fhs.upr.si/sl/oddelki/ oddelek-za-arheologijo-in-dediscino $>$.

STOKIN, Marko and Katharina ZANIER. Simonov zaliv / San Simone. Ljubljana: ZVKDS, 2011. Vestnik, vol. 23. ISBN 978-961-6420-79-2.

UNESCO Chair of Museology and World Heritage [online]. [accessed 2018-02-12]. Available from www: $<$ https://archeo-muzeo.phil.muni.cz/en/about/katedra --unesco $>$.

UNESCO UNITWIN Underwater Archaeology Network [online]. [accessed 2018-02-12]. Available from www: <http://www.fhs. upr.si/en>.

University of Primorska, Faculty of Humanities [online]. [accessed 2018-02-12]. Available from www: <http:// www.fhs.upr.si/en>.

ZANIER, Katharina. La villa maritima di S. Simone a Izola/Isola (Slovenia). Progetti e interventi per la valorizzazione scientifica e turistica. In
CORALINI, Antonella (ed.). Vesuviana. Archeologie a confronto. Atti del convegno internazionale (Bologna, 14-16 Gennaio 2008). Bologna: Ante Quem, 2009, pp. 321-328. ISBN 978-88-7849-043-7.

\section{IRENA LAZAR}

Department/Institute for Archaeology and Heritage, Faculty of Humanities, University of Primorska, Koper, Slovenia

irena.lazar@fhs.upr.si

Irena Lazar is an archaeologist, Dean of the Faculty of Humanities and a professor for ancient archaeology, history and heritage. She graduated and received her PhD at the University of Ljubljana. Her research covers the field of archeology, heritage and historiography, with a focus on Roman archaeology, ancient glass and material culture of the Roman provinces. She worked as a museum curator for 17 years. Since 2005 she has worked as a professor at the University of Primorska, and since 2008 she is full time employed at the University on the programs of Cultural Heritage and Archaeology and mentors students at all levels of study. She also teaches at the Faculty of Tourism Studies at the program of Heritage Tourism. She organized numerous conferences, researched and published at home and abroad and led national and international projects. She is also responsible for the management of the Archaeological park Simonov zaliv in Izola.

Irena Lazar je archeoložkou, děkankou Fakulty humanitních studií a profesorkou archeologie starověku, historie a ochrany kulturního dědictví. Vystudovala na Univerzitě v Lublani, kde získala i doktorát. Ve své vědecké práci se zaměřuje na archeologii, kulturní dědictví a historiografii, zejména na archeologii starověkého Říma, antické sklo a materiální kulturu římských provincií. Sedmnáct let pracovala jako muzejní kurátorka. Od roku 2005 působí jako profe- sorka na Univerzitě v slovinském Přímoří, od roku 2008 zde vyučuje na plný úvazek v rámci studijních programů Kulturní dědictví a Archeologie a vede studenty na všech úrovních studia. Přednáší také na Fakultě cestovního ruchu v rámci studijního programu Kulturní turismus. Byla organizátorkou řady odborných konferencí, prováděla výzkum a publikovala doma i v zahraničí a stála v čele domácích i mezinárodních výzkumných projektů. Má na starost správu archeoparku Simonov zaliv v Izole.

\section{ZRINKA MILEUSNIĆ}

Department/Institute for Archaeology and Heritage, Faculty of Humanities, University of Primorska, Koper, Slovenia

zrinka.mileusnic@fhs.upr.si

\section{Zrinka Mileusnić is an}

archaeologist at the Institute and Department of Archaeology and Heritage at UP FHŠ. She graduated and received her master's degree at the University of Ljubljana and received her $\mathrm{PhD}$ at the University of Primorska. Her research covers the field of archeology, heritage and historiography, with a focus on medieval and post-medieval archaeology and material culture of the Adriatic area. Since 2004, she has worked as a researcher at the University of Primorska, and since 2008 she has also been a lecturer at UP FHŠ on the programs of Cultural Heritage and Archaeology. She also teaches at the Faculty of Tourism Studies at the program of Heritage Tourism and mentors students at all levels of study. She collaborated and led national and international projects, organized numerous conferences, researched and published at home and abroad. She is a member of international and national professional associations.

Zrinka Mileusnić je archeoložkou na Ústavu a katedře archeologie a kulturního dědictví na Fakultě humanitních studií Univerzity v slovinském Přímoří. Magisterské 
studium absolvovala na Univerzitě v Lublani a doktorát získala na Univerzitě v slovinském Přímoří. Ve své vědecké práci se zaměřuje na archeologii, kulturní dědictví a historiografii, zejména na archeologii středověku a raného novověku a materiální kulturu v oblasti Jadranu. Od roku 2004 je zaměstnaná jako odborná vědecká pracovnice na Univerzitě $\mathrm{v}$ slovinském Přímoří a od roku 2008 zde na Fakultě humanitních studií vyučuje v rámci studijních programů Kulturní dědictví a Archeologie. Přednáší také na Fakultě cestovního ruchu v rámci studijního programu Kulturní turismus a vede studenty na všech úrovních studia. Účastnila se a stála v čele domácích i mezinárodních výzkumných projektů, organizovala řadu odborných konferencí, prováděla výzkum a publikovala doma i v zahraničí. Je členkou mezinárodních i národních odborných organizací a sdružení. 